\title{
THE IMPACT OF USING INFORMATION TECHNOLOGY AND COMMUNICATION IN SCHOOLS IN ROMANIA
}

\author{
Alina-Andreea Marin \\ The Bucharest University of Economic Studies, Romania \\ alina.marin@man.ase.ro \\ Adina Liliana Prioteasa \\ The Bucharest University of Economic Studies, Romania \\ prioteasaadina@gmail.com
}

\begin{abstract}
New technologies are a catalyst for education. Technology unlocks educational boundaries, motivates students, improves students' writing and learning skills, promotes individual learning. This sector has become an educational priority and all EU countries are striving to develop ICT skills. Technology is part of the world we live in. Most jobs today require the use of technology. For this reason, the focus is on developing a set of knowledge, skills, attitudes, necessary for access to the labor market, social inclusion, personal development and lifelong learning. The knowledge society has imposed the use of ICT as a necessary condition for the integration of the individual in the labor market and in society. The present paper attempts to provide an overview of the impact that technology has on pupils and teachers in Romanian schools.

Keywords: ICT, education, the knowledge society, innovation, digital methods
\end{abstract}

\section{INTRODUCTION}

Information and communication technology (ICT) have become the main goal of the 21st century to be socially, economically and culturally integrated. The knowledge economy implies the integration of knowledge flow, information, people and services using the technology of knowledge and communication.

Education is a major sector that has undergone the influence of ICT innovations. The learners must be able to access, integrate and evaluate information, develop their knowledge and communicate with others in order to be active citizens in an increasingly complex and rich world of information and knowledge. 
ICT transforms not only the teaching process, but also the learning processes. ICT has led to a substantial increase in the preparation, planning and administration of lessons, but also an increase in the use of these technologies even in the teaching and learning process.

Information and communication technology make all schools "smart". Students, teachers and educational administrators, as well as all the factors involved in education, have benefited and benefit from the integration of ICT in education.

The Organization for Economic Cooperation and Development (OECD) monitors the way students' access and use information and communication technologies. The OECD tracks and analyzes how school education systems integrate ICT into students' learning experiences.

Based on international PISA tests from over 70 countries and based on reports, the OECD examines the impact of technology in schools. PISA tests measure digital, mathematical and reading skills.

The present paper attempts to highlight the impact that information and communication technologies have on schools in our country. The working hypotheses that were the basis of the paper are the following:

> If digital tools are frequently used in students' activities, their creative capacities are stimulated, and their academic performance is increased.

$>$ If schools are equipped with digital equipment, an active, conscious and creative participation of students in instructional activities is achieved.

$>$ If students have solid knowledge, skills and abilities in the field of information technology and communication, they can creatively fulfill tasks that require their use in a completely different vision.

> If the digital methods are currently used in the activities with the students, the desire to learn, the curiosity and the initiative of action are stimulated and thus their degree of motivation increases.

The purpose of this research is to analyze the level of integration of information technology in didactic activity.

The research objectives are: surprising the impact on educational activities of using information and communication technology and diagnosis of the essential aspects regarding the use of ICT in school. For the first objective, to surprising the impact on the educational activity, the opinions of the teachers regarding the integration of technology in the didactic activity associated with the evaluation of classroom experiences are relevant. Regarding the second objective, diagnosing the essential aspects regarding the use of ICT in the school, we look at the existence of the infrastructure, the frequency and 
nature of the use of computers, the difficulties related to all these aspects, the difficulties of the students as well as the teachers.

The research was designed to clarify the following aspects:

$>$ identifying the technological resources of schools (equipping the schools with digital equipment);

$>$ highlighting the types of instruments used (integration of technologies by teachers in pedagogical practices);

$>$ knowledge of how to integrate digital instruments;

$>$ capturing the positive impact of using technology;

$>$ discovering the challenges encountered by the teachers;

$>$ identifying sources of funding for schools regarding the provision of digital instruments.

\section{LITERATURE REVIEW}

"The computer revolution extended to other plans (the first global revolution) is a threshold for the entry of modernity into a new phase, which, after exceeding a transition period, acquires the outline and coherence of a paradigm that can become emblematic in the 21st century: geomodernity" (Malița, 1998).

The use of ICT in the process of teaching - learning is used because of the need to create new aspects of education that fit the twenty-first century, such as the use of videos (Ebrahimi, 2013). This aims to change attitudes, values and aspirations in accordance with the current global benefits of modernization. Therefore, the adoption of ICT in the field of education becomes appropriate for individuals' development.

The need for technological innovation has brought up a revolution in the development of technology and communication application in education. This has contributed to the development of educational systems. Teachers quickly realized that using computer-assisted education and digital learning is effective for users (Ebrahimi, 2016).

"The knowledge economy changes all the data of education. The education systems formally try to adapt to this new situation, in which the whole world is a school class. The introduction of computer science in schools was the first step. Program flexibility and optional courses, another. The introduction of visits and study placements outside the school, at productive institutions, services or administration, third. The annual revision of the textbooks was undertaken. The manual becomes a basic guide, and knowledge is acquired from the sources recommended in bibliographies. From the lesson, the focus has been shifted to individual or teamwork. Teachers become tutors, guides or facilitators of students' 
personal work. The school library becomes media and the $C D$ shelf is more researched than the bookshelf. Furtively, students have fun with computer games. But a multimedia history lesson or visits to monuments, can be more absorbing than any game and it beats by far the classic presentation using the textbook (Malița, 1998).

The World Summit on the Information Society (WSIS) took place in two phases. The first phase took place in Geneva, December 10-12, 2003, and the second phase in Tunis, November 16-18, 2005. Through the SCCD-ICT project, UNESCO (2003) responds: to its agency function responsible for setting standards, to its mandate in within the framework of the Education for All Program, its mandate as the main agency responsible for the $\mathrm{C} 4$ action lines for "capacity development" (together with UNDP) and C7 for "e-learning" of the Geneva Action Plan adopted at the Summit World on the Information Society1 and its general objective to build inclusive societies based on knowledge through ICT.

Technology has been successfully used by teachers to provide students with more accentuated and individualized feedback. Most of the students surveyed (90.4\%) out of a sample of 3953 students believe that those who do not have access to a computer will be disadvantaged later, and $8.7 \%$ believe that the problem of internet access is not decisive. $87 \%$ of students acknowledge the danger posed by the excessive use of the computer, only $12.1 \%$ of them considering that excessive use cannot have negative effects (Potolea et al., 2008).

Regarding vocational training and insertion in the labor market, the utility of ICT is obvious for $98 \%$ of the teachers. Technological competence is a primary competence in the practice of most professions.

The use of ICT at school can help reduce social divisions by reducing the digital divide (Balanskat et al., 2006). Most of the training providers in the workplace $(72 \%)$ and the majority of professionals $(81 \%)$ agree that information and communication technology has led to an increase in the continuous learning opportunities available (Becta, 2008).

Digital skills are essential for "a world of rapid change". CRF and Associates, 2001. 80\% of teachers agree that technology has an impact on students' involvement in learning. Teachers have found that using technology to facilitate creative, project-based learning can motivate dissatisfied students in school (Becta, 2008).

By applying the Plato Learning program, have been noticed the importance of using the technology by the members of the community and the support for its application at the maximum efficiency level, as well as facilitating the implementation of the law "No child is left behind". Community members want to work or already work with the school to develop policies and strategies to increase the use of technology in the community. 
"The processes of successful implementation of the new technologies are conditioned by the following factors: favorable organizational conditions (pedagogical vision, educational policy and school culture); transparent collaboration between the different professional categories (teachers, management team, technical department, etc.); favorable material conditions (infrastructure, material basis)" (Toma et al., 2009).

In Romania, there are between 7 and 68 computers in rural schools and between 10 and 157 computers in urban areas. They are connected to the Internet $73.4 \%$ (Potolea et al., 2008). ICTs are used to reduce the expenses associated with the training process. Technology can improve access to quality education. ICT facilitates the provision of virtual and interactive learning experiences (Kozma, 2005).

For the school managers, the elaboration of educational projects in collaboration with other schools or other institutions of the civil society constitutes the priority direction of development for the use of ICT 3,4 (on a scale 0-5) (Potolea et al., 2008). An ICT training program, conducted in 10 countries in Asia, has opened up new opportunities for new partnerships, learning communities, at local, regional and national levels, generating and sustaining positive results at all levels (Oakley, 2014).

Teachers state that ICT contributes to the greatest extent to facilitating the achievement of the lesson $(1,856$ on a scale $0-3)$, followed by the facilitation of the teaching activity. In the plan of benefits for students, teachers consider that ICT promotes active, interactive, participative learning (1,787 on $0-3)$. $50 \%$ of teachers find that the use of new technologies contributes substantially to the adequate achievement of a differentiated education with students (Potolea et al., 2008).

ICT allows students to work according to their own learning styles. Collaboration between students is better when using ICT (Balanskat et al., 2006). New technologies facilitate the rapid transition from the lecture-based teaching model to the student-centered model that encompasses constructive teaching / learning strategies. The teachers have stated that they need to change their thinking about their work and that the use of laptops requires a greater planning of lessons (Hill, 2003).

The online tools for training and assessment provided teachers with immediate feedback on student activity and new resources for planning personalized training on the Internet, when remedial or diversification actions were needed. Most teachers assert that their workload has increased due to the extra administrative tasks and the need to plan some extra-curricular activities related to the use of computers by students (Kerr et al., 2003).

$70.2 \%$ of the teachers note the positive impact of ICT on the achievement in the discipline they teach. ICT has a positive impact to a greater extent on good students (49.1\% of teachers, $82 \%$ of students) and less on weak students (37.5\% of teachers, $69.8 \%$ of students (Potolea et al., 2008). 65\% of teachers stated that students worked together more than before, on comparable tasks, $60 \%$ of teachers 
believe that the integration of ICT in the lesson facilitates the understanding of the content by the students (Toma et al., 2009).

Several other studies have shown the importance of technology in increasing students' outcomes and performance, such as: better learning, better school outcomes, improving students' outcomes in civic and mathematics education, developing technology and technology skills. Competences for the $21 \mathrm{st}$ century, increasing the quality and complexity of students ' products, increasing the quality of students' written work, developing the cognitive skills that students use in school tasks, higher grades in tests, improving student involvement, motivation and their ability to work independently, participating in classes, interacting with colleagues and teachers, improving lesson preparation, improving reading and writing skills (especially for students with low skills), engaging students-in -risk in learning activities, high school collaboration projects, higher scores on English tests and better writing results: ideas, content, organization, style (Istrate, 2000).

Robert Kozma notes that "there can be no expectations regarding progress in learning by simply introducing ICT in schools" (Kozma, 2005).

\section{METHODOLOGY}

Between February $15^{\text {th }}$ and June $15^{\text {th }}, 2019$, a quantitative research was conducted to interview teachers from Buzau County. This quantitative research was conducted online. Questionnaires were applied to 204 schools in primary, secondary and high school both in urban and rural areas. 182 teachers answered, and the results are analyzed and concluded in the following rows.

Using the questions in the questionnaire we wanted to find out if schools are equipped with digital tools, what digital tools are used in schools, if teachers integrate these technologies into their pedagogical practices, in what context teachers use digital tools and what is the positive impact found after using digital tools in pedagogical practices, what challenges teachers face in integrating digital instruments into their pedagogical practices and where the funding needed to purchase digital instruments comes from.

TABEL 1. DISTRIBUTION OF THE SCHOOLS PARTICIPATING IN THE RESEARCH

\begin{tabular}{|l|l|l|}
\hline TYPE OF SCHOOL & URBAN AREA & RURAL AREA \\
\hline PRIMARY/SECONDARY SCHOOL & 33 & 110 \\
\hline HIGH SCHOOL & 59 & 2 \\
\hline
\end{tabular}

Source: Authors 
Educational institutions for the urban environment represent $45.09 \%$ and the famous one from the rural area $54.09 \%$. The large number of educational institutions in the rural area is given by the primary and secondary schools are filled in the villages and communes of Buzau county. All schools in the urban area answered the questionnaire, and those in the rural area accounted for $80 \%$.

\section{Are primary schools equipped with digital tools?}

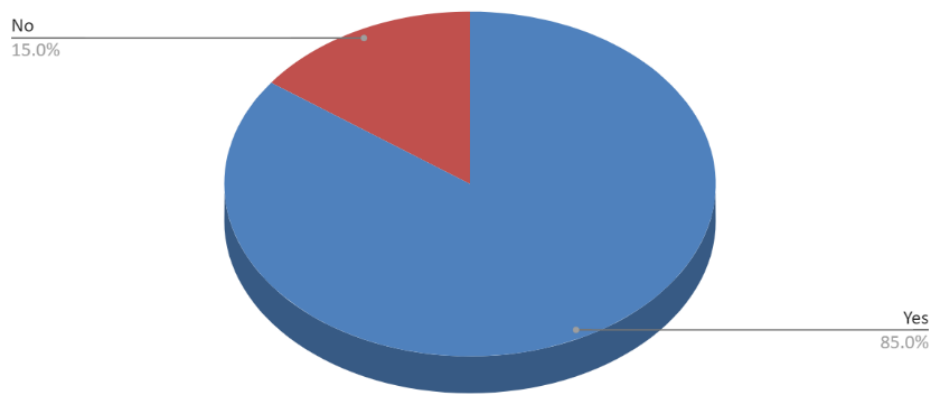

\section{Are secondary schools equipped with digital tools?}

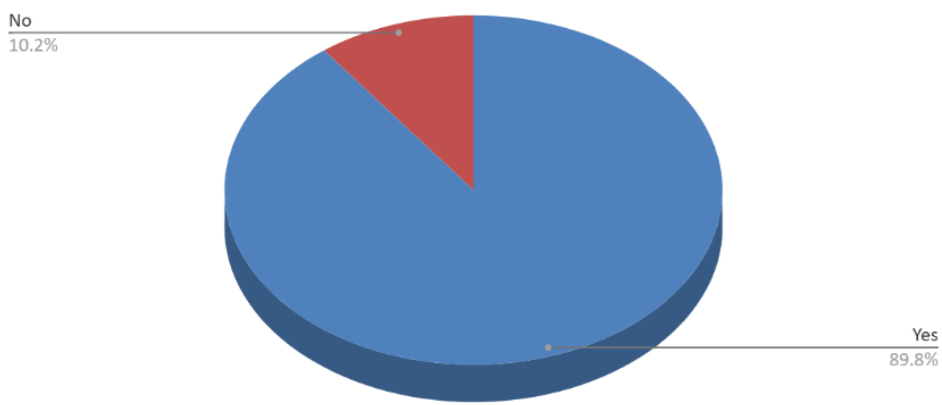

FIGURE 1. PROVIDING SCHOOLS WITH DIGITAL TOOLS

Source: Authors

According to the data obtained, most (over $80 \%$ of schools) are equipped with digital tools such as: interactive digital blackboard, computer, laptop, school portal, school Facebook page, tablet, smart phone. Although we have this favorable situation, according to European Schoolnet statistical data, in Romania there are considerably fewer computers available for all students than the EU average so in the 8th grade Romania is at a lower level with 13 students on the computer, and in the other classes we have and 10-17 students on the computer. 


\section{In primary schools equipped with digital instruments, teachers integrate these technologies into their practices}

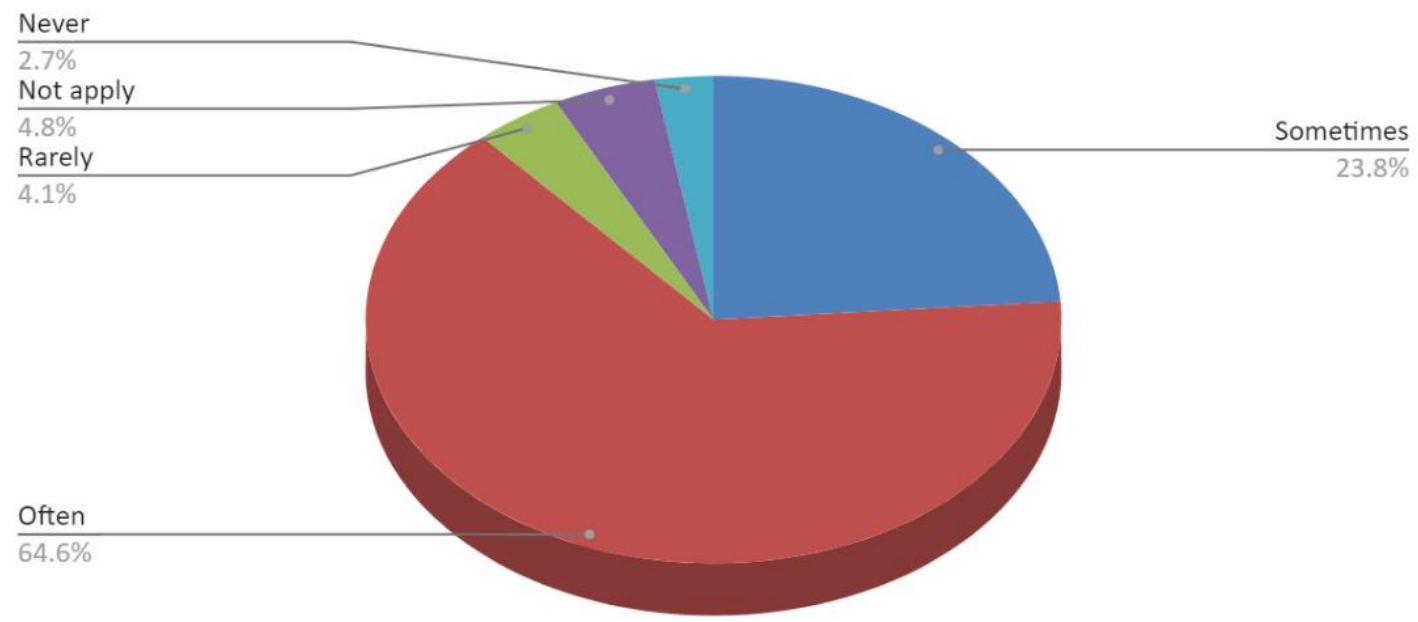

FIGURE 2. THE DEGREE OF USE OF ICT IN EDUCATION

Source: Authors

The results show that teachers often use digital tools. Thus, he adopted a positive attitude towards the use of ICT in school. There are very few who do not use digital tools in pedagogical practices. ICT presents a number of tools that teachers use to present and display as part of their teaching and help them interact with students as well as engage them more effectively. Teachers design their students' learning activities and are thus instrumental in implementing digital learning practices. Most students now have teachers who often use digital technologies (55\% at primary level and $67 \%$ at upper secondary level).

Based on the data obtained from the page of the county school inspectorate in Buzau, it can be observed that most of the schools in the county have a web page, about $90 \%$. Analyzing these web pages, you can find that they are permanently updated. This shows us that schools are adequately digitally equipped, use technology and integrate it into managerial activity. The units that do not have a web page are kindergartens or schools in rural areas and represent only $10 \%$.

What is the positive impact of using digital tools in pedagogical practices? 


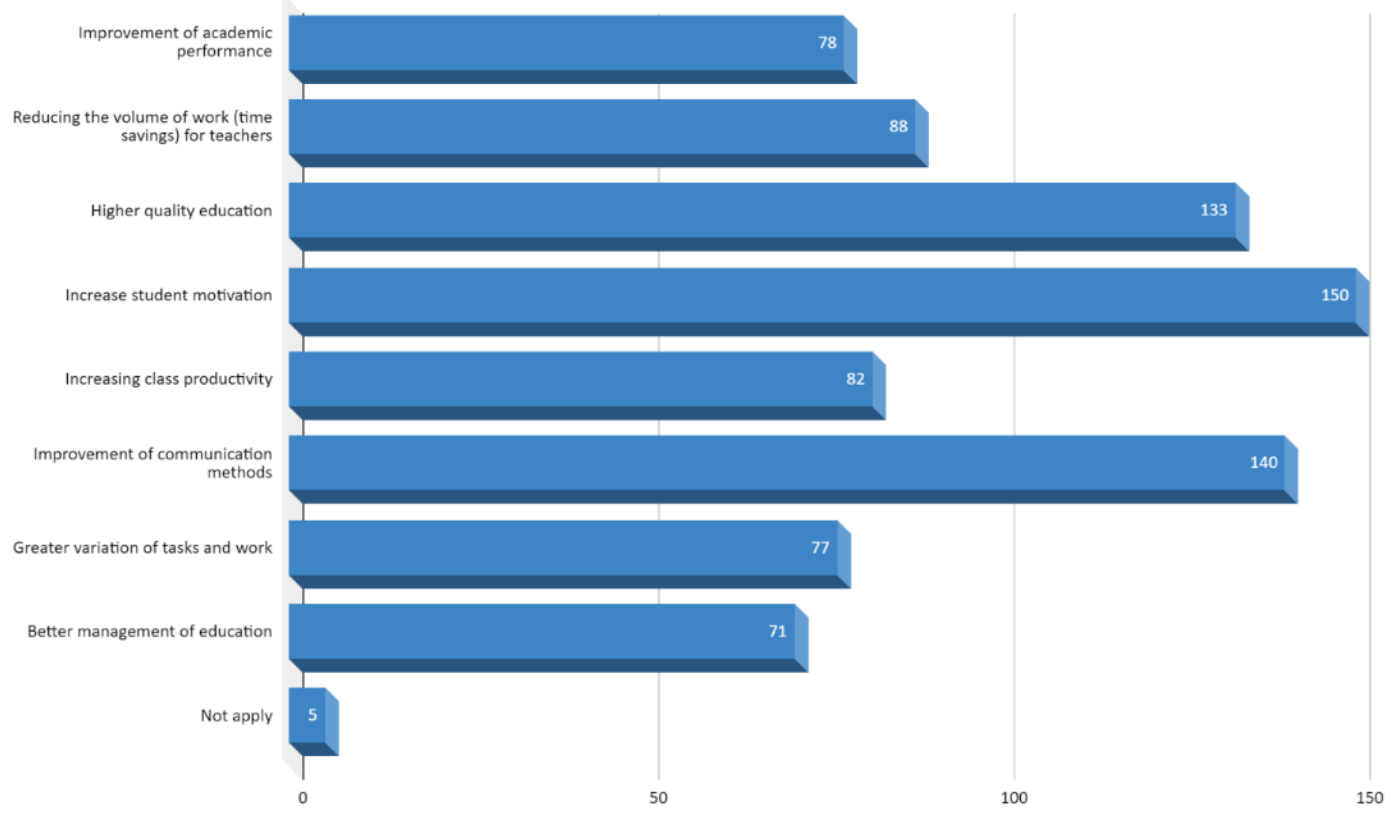

\section{FIGURE 3. IMPACT OF ICT USE IN TEACHING ACTIVITY}

Source: Authors

ICT allows students to get involved in the learning process and gives them an interest in personal education. Technology offers different opportunities to make learning more fun and enjoyable in teaching the same things in new ways. By integrating ICT into the classroom, students can learn more effectively, to collaborate with each other, and to explore the world around them. They are more active in learning and increasing self-esteem. The use of technology in the educational environment increases the academic performance, increases the motivation of the students for the study, supports the increase of the productivity of the class and improves the communication methods. By using technology in the classroom, both teachers and students can develop skills that are essential to the 21 st century. 


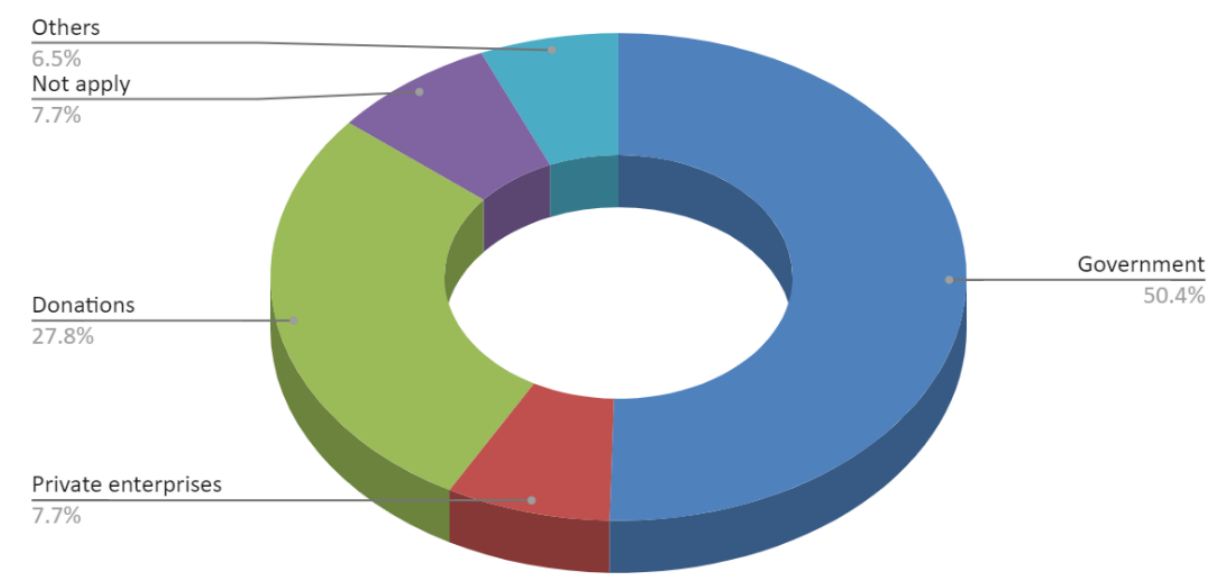

FIGURE 4. SOURCES OF FINANCING FOR THE PURCHASE OF DIGITAL INSTRUMENTS

Source: Authors

It is found that most schools have digital instruments obtained with money from the government (50.4\%). Private companies have also supported schools, but the percentage is quite small $(7.7 \%)$. Donations represent $27.8 \%$. The educational units, especially the vocational schools, should attract more funds from the practical partners. Most countries had national strategies to support the use of ICT in education. Digitization continues in a fairly alert manner, and countries must continually review and renew their approaches and strategies regarding digital education in schools. The Romanian government will have to permanently support the educational system in order for it to cope with the new technologies.

\section{CONCLUSIONS}

The positive impact that the teachers find is materialized in the improvement of the academic performance, the reduction of work volume (time savings) for teachers, better quality education, increase of students' motivation, increase in class productivity, improvement of communication methods, greater variety of tasks and work, better education management.

The impact of technology in education is obviously below the optimal level for several reasons: overestimation of students' and teachers' digital skills, policies that are unrealistic in terms of implementation, poor understanding and preparation from a pedagogical point of view, poor quality of training courses and existing educational software. The results show that, although they are aware of 
the importance of ICT and have a positive attitude towards the use of ICT in schools, most of the teachers included in the study consider that they are poorly prepared and want to deepen their knowledge in this field during continuous professional training. First, teachers need sufficient ICT skills to use the technology and feel confident enough to use them during class hours. Secondly, teachers need knowledge about the pedagogical role of ICT, in order to use it significantly in teaching and assessment.

Education, vocational training and lifelong learning play an essential role in the economic and social strategies of the European Union. The aging of the population leads to an increase in the demographic report of dependency of the elderly for all the Member States of the European Union.

In the last years, due to the technological advances, the share of the population of level 3-8 of education has increased, and the cities offer the highest weight for 5-8. The analysis shows that, at European level,in 2004, the share of the population with level 5-8 education was $26.9 \%$. In 2018 , this indicator rose to $40.7 \%$ (Basic Indicators on the Incorporation of ICT into European Education Systems).

Based on the results obtained from the present research, we propose two future ways of integrating information technology into the didactic activity: developing and disseminating a new methodology based on the use of ICT in the didactic activity; training and improvement of teachers on digital skills. It is useful to set up projects with teachers and students from different schools, who collaborate by using digital technologies. ETwinning projects, for example, provide a new opportunity for teachers for on-thejob training in digital professional learning communities. ETwinning mainly covers school curriculum subjects and uses digital technologies to cover a wide variety of topics.

Providers of initial and continuous training: Ministry of Education, Research and Innovation (MECl), Departments for Teacher Training (DPPD), National Center for Curriculum and Evaluation in Preuniversity Education (CNCEIP), Department of the Teaching Staff (CCD), NGOs can propose and develop programs that support teachers in improving the use of information and communication technology in the classroom, can support students by facilitating their access to the much needed digital tools. Based on the data provided by this research, but also on the basis of other researches, the needs of the education system can be correctly identified, and action can be taken accordingly.

The connections between students, computers and learning are neither very simple nor very confusing. The impact and contribution that ICT can make to the learning process is a very complex one that has not been fully exploited. The impact of ICT on educational quality is revealed by the way technology is used. ICT is not a technical implementation, but a continuous process of educational change.

ACKNOWLEDGEMENTS: This study is the result of the research carried out within the doctoral studies programs of the Bucharest University of Economic Studies, Doctoral School of Management. 


\section{REFERENCES}

Balanskat, A., Blamire, R. and Kefala, S. (2006). The ICT Impact Report. European Schoolnet. Retrieved January $12^{\text {th }}, 2020$, from http://ec.europa.eu/education/pdf/doc254_en.pdf

Becta, (2008). Harnessing Technology Review: The role of technology and its impact on education.London: BECTA. 2008.

Ebrahimi, SS. (2013). Teaching English by Video Technology, NewLiteracies: Reconstructing Education and Language. Ambigapathy Pandian, et. al. (Eds). Newcastle upon Tyne. UK:Cambridge Scholars

Ebrahimi, SS. (2016). Effect of digital reading on comprehension of English prose texts in EFL/ESL contexts, Int. J. English Language and Literature Studies. 5(2): 111-117

Hill, J. R. et al. (2003). The Impact of Portable Technologies on Teaching and Learning: Year One Report and Year Two Report, Dept. of IT at the University of Georgia (U.S.), for Athens Academy

Istrate, O. (2000). Educația la distanță. Proiectarea materialelor. Botoşani: Agata

Kerr, K. A., Pane, J. F., \& Barney, H. (2003). Quaker Valley Digital School District: Early Effects and Plans for Future Evaluation. Santa Monica, CA. Retrieved January 12th 2020 , from http://192.5.14.110/pubs/technical_reports/2004/RAND_TR107.pdf

Kozma, R. B. (2005). National Policies that Connect ICT-based Education Reform to Economic and Social Development. Human Technology, SRI International, University of Jyvaskyla. Retrieved February 15 $5^{\text {th }}, 2020$, from http://www.humantechnology.jyu.fi/articles/volume1/2005/kozma.pdf

Malița, M. (1998). Zece mii de culturi o singură civilizație, Editura Nemira, București.

Oakley, G., Pegrum, M., \& Johnston, S. (2014). Introducing e-portfolios to pre-service teachers as tools for reflection and growth: lessons learnt. Asia-Pacific Journal of Teacher Education, 42(1), 36-50.

Potolea, D., Noveanu, E., Velea, S., Botnariuc, P., Novak, C., Istrate, O. (2008). Informatizarea sistemului de învățământ: Programul S.E.I. Raport de cercetare evaluativă. București: Universitatea din Bucuresti, Facultatea de Psihologie și Științele Educației.

Toma, S., Gabureanu, S., Fat, S., \& Novak, C. (2009). Teaching in the Knowledge Society: The Impact of the Intel Teach Program in Romania. Bucharest: Agata Publishing House.

UNESCO Institute for Information Technologies in Education (2003). http://unesdoc.unesco.org/images/0013/001330/133024eo.pdf (accessed 2020)

UNESCO Institute for Statistics. (2009). Guide to Measuring Information and Communication Technologies (ICT) in Education. Technical Paper No. 2. Montreal 